\title{
The BDU West between WWII and Cold War
}

\author{
Giancarlo T. Tomezzoli \\ Etno-Archaeological Observatory, Munich, Germany \\ Email: gt21949@gmx.de
}

How to cite this paper: Tomezzoli, G. T. (2019). The BDU West between WWII and Cold War. Archaeological Discovery, 7, 1-19. https://doi.org/10.4236/ad.2019.71001

Received: November 9, 2018

Accepted: January 12, 2019

Published: January 15, 2019

Copyright $\odot 2019$ by authors and Scientific Research Publishing Inc. This work is licensed under the Creative Commons Attribution International License (CC BY 4.0).

http://creativecommons.org/licenses/by/4.0/

\begin{abstract}
In this article the recent history of the Domaine de Pignerolle, near Saint-Barthelemy d'Anjou, the organization of the BDU West and its role during the WWII, the after war and the Cold War are described. The visits on the BDU site showed that all the BDU barracks disappeared and all the BDU bunkers were in good preservation state. In particular, the visit of the Admiral bunker showed that its transformation in anti-atomic bunker for the French president and government was in an advanced phase, but not terminated and consequently it never was operative. The reasons of this transformation, despite the existence of other similar anti-atomic bunkers, and of its interruption remain to be determined.
\end{abstract}

\section{Keywords}

WWII, Cold War, Atlantic Wall, BDU West, Admiral Bunker, Pignerolle, Anjou, France

\section{Introduction}

The first visit of the Domaine de Pignerolle on $22^{\text {nd }}$ August 2011 allowed identifying various BDU West bunkers, verifying their preservation state and identifying the BDU West role during the WWII. At that time, the Admiral bunker was not accessible; therefore the inspection of its interior was not possible. Only recently the Angers public administration given to the Association "Les Oubliés de Pignerolle" the task of supervising the bunkers preservation together with all the necessary authorizations and means for accessing them. The second visit on $16^{\text {th }}$ September 2016, allowed reconstructing the BDU West organization and the evaluation of the transformation of the Admiral bunker, during the Cold War, in anti-atomic shelter for the French president and government.

\section{Recent History of the Domaine de Pignerolle}

The family Avril was proprietor of terrains around Saint-Barthélemy-d'Anjou 
(Angers) already from 1680. She gave two canonicals to the Angers church and many directors to the Academie d'Equitation d'Angers. At the beginning of the XVIII cen., she purchased further terrains on the municipality of Saint Barthélemy and formed the Domaine de Pignerolle. On 1776 Mr. Marcel Avril lord of Pignerolle and Chauffour, director of the Academie, given to the architect Bardoul de la Bigotière the task to construct on the Domaine his castle. The castle was neoclassic in style, with a front and rear facades having seven bays and sides facades having five bays. The front facade comprised a front porch formed by four cylindrical, channelled columns, having ionic tops decorated with garlands and pendants, supporting a protruding balcony. Three bas-reliefs representing respectively: an angel presenting a rule and a compass to a lying vestal on the left, Apollo with the lyre at the centre, and angels crowning Aphrodite on the right, were on the front facade between the columns. The rear facade comprised four slightly protruding rectangular, channelled columns supporting a top fronton. Three bas-reliefs decorated by scrollwork and garlands were between the columns. Each window was surmounted by a fronton. The roof Italian in style was contoured by a balustrade. The apartments of Mr. Avril, were at first floor with a cabinet and a library. The park was a mix of French and English style garden (Coiffard, 2006).

The Academy admitted students from many European countries. On $16^{\text {th }}$ January 1786 Arthur Wesley, future Duke of Wellington, arrived in Angers. At the Academie he learned dance, mathematics, languages, the use of weapons, and in the woods of the Domaine to be chevalier. Other relevant students of the Academy were brothers De Witt, stadtholders in Holland, the naturalist Buffon and the future statesman William Pitt. The Academy closed on 1792 at the time of the Revolution. Mr. Avril was arrested on October 1793 and imprisoned in Angers. The castle was occupied by revolutionaries and signets were posed on its doors. The Avril family migrated to another residence (Coiffard, 2006).

On XIX cen. the Domaine was sold by the descendants of Mr. Avril to Mr. P-A Blancler, rich Angers merchant. He renewed the castle in the $1^{\text {st }}$ Empire style, built the orangery, a slate wall long several kilometres around the Domaine, two pavilion tours and grids at the Domaine entrance. After him, the Domaine was acquired by different families for arriving on 1905 in the patrimony of the viscount Joseph Coudrec de Saint-Chamant. He was graduated officer from the Saint-Cyr Academy, captain of the $27^{\text {th }}$ Dragoons at Versailles and in service at the War Minister from 1900 to 1906. The WWI caused him to resume military service and the loss of his son Guillaume. In his memory, the viscount founded in Saint-Barthélemy the Saint-Guillaume school. The park was many times open to feasts, concerts and religious, rogation processions (Coiffard, 2006).

On $1^{\text {st }}$ September 1939 Germany invaded Poland. Great Brittany and France declared war to Germany and mobilized their troops. The $125^{\text {th }}$ Infantry Regiment was formed on the Domaine on $2^{\text {nd }}$ September. Its headquarter and the 
residence of its commander colonel Tauréu were on the Domaine. The regimental sections were lodged in the farms of the nearby municipality of Saint-Barthelemy, trained on the Domaine and tried their regulatory gas masks in the pavilion tours. Many horses were requisitioned, regimental arms and materials deposited at the garage Hutreau. The majority of the soldiers were Angers natives and went home each evening. On $9^{\text {th }}$ September 1939 the Regiment received its flag in front of the castle porch for. On $13^{\text {th }}$ September the last Regiment elements leaved the Angers Saint-Laud station for the Meurthe-et-Moselle region (Coiffard, 2006).

After the Polish army defeat in September 1939, in October 1939 the viscount received the castle requisition by a letter of the Anjou prefect, as consequence of the French Republic president decree about the nation war time organization. He did not oppose the requisition and leaved the castle. Upon invitation, the Angers authorities assigned different Angers residences to the Polish government in exile, residences around Angers to the polish ministers and accredited foreign embassies. The castle was residence of the Polish president Raczkiewicz, who took possession on $2^{\text {nd }}$ December 1939. The activities, the choices and the correspondence of the Polish government were controlled and protection was assured against its opponents. A Polish army of 80,000 escaped Polish soldiers and migrated workers was formed and positioned to defend France strategic points. The rapid German invasion of France on June 1940 obliged, on $12^{\text {th }}-14^{\text {th }}$ June 1940, the Polish government and president to leave for Great Britain. An English headquarter was at the castle for only two days. The Polish army was evacuated to Great Britain. On $17^{\text {th }}$ June 1940 a Luftwaffe attack in the Loire estuary sank the ship Lancastria causing the death of many British, Polish and Czech soldiers (Coiffard, 2006; Lemesle, 1981).

The Kriegsmarine decision on 1943 to move the West headquarter of the commander of U-Bootes (Befehlshaber der Unterseebootes West, BDU West) admiral Dönitz briefly to Parisand subsequently to the Domaine, ideal for the absence of relevant radio interferences, was consequence of the $28^{\text {th }}$ March 1942 $R A F$ air raid on the $\mathrm{U}$-Boote base of Saint-Nazaire and the menaces to the $\mathrm{U}$-Boote base of Lorient and to the BDU West itself in Le Kernevel (LarmorPlage). Six hundred foreign workers built on the Domaine a base named, according to German Angers defence maps, simply BDU. It comprised eleven bunkers and twenty barracks for hosting about thousand German seamen and about ten French servants. Many trucks, requisitioned in Paris, transported cement and sand arriving at La Pyramide station at the BDU. Two hangars of the farm Ambillons stocked the cement sacs (Coiffard, 2006).

The BDU commanded the Melun Saint-Assise transmission station connected to a $1 \mathrm{~km}$ long antenna for long wave transmissions and the French navy T.S.F. (Télégraphie Sans Fil - wireless) station of Basse-Lande (Brains). The BDU was connected to La Reux bunker in Saint-Barthélemy (Tomezzoli, 2018) a long range emission station used as auxiliary emitter and emergency antenna. A relay 
at college Du Bellay in Angers completed the BDU. The French farmers had to leave the cultivations because of the guards around the BDU bunkers. The vessel captain (Kaptänzur Zee) Rösing had the BDU commandment dependent from the Kriegsmarine Upper Command (Oberkommandoder Kriegsmarine - OKM) at Koralle Lager near Berlin (Coiffard, 2006).

The BDU assembled and coordinated all the available information coming from centres on the North Sea, Tyrrhenian Sea, Aegean Sea, Black Sea, Indian Ocean and from Kondor planes of the Luftwaffe Atlantic headquarter (Flieger Führer Atlantik) based at Merignac (Bordeaux). The actions of the U-Boote flotillas of Brest, Lorient, Saint-Nazaire, La Pallice and Bordeaux were commanded directly from the BDU, which was never bombarded notwithstanding the information sent to London by French resistance networks. The allied probably found more fruitful to intercept messages to and from the BDU rather than to destroy it. The BDU was also a rest place for U-Bootes crews, which on free time played sports and hockey on the Domaine meadows. Admiral Dönitz visited frequently the BDU, which received also visits of Italian BETASOM admiral and officers based in Bordeaux and of a Japanese officer delegation. A foreseen Hitler's BDU visit never took place (Coiffard, 2006; Suquet, 2009; Suquet, 2010).

On $9^{\text {th }}$ August 1944, after the German defeat in the Angers battle, Rösing abandoned the BDU after having ordered to set the Admiral bunker on fire. After four days the French firemen were still unable to turn off the main fire source. On the fifth day the firemen chief ordered the closure of the bunker armored, gastight doors to stifle the fire. The fire persisted still some day before to turn definitively off. The BDU was looted by the French population (Gautier, 1973).

American black troops sojourned in the BDU during the harsh winter 1944-45. After them, from April to November 1945 the BDU lodged a Jewish colony together with prisoners and deported people of different nationalities waiting repatriation. From $3^{\text {rd }}$ January 1946 following the decree of Angers major Allonneau and up to 1964, the BDU served as provisory accommodation for about thousand Angers war victims and deported peoples, and hosted a school, a police station and a church located in the orangery. Two barracks burned respectively on 1958 and 1961. After the WWII, during the Cold War, the Admiral bunker undergone works to transform it in anti-atomic bunker for the French president and government (Coiffard, 2006).

\section{The BDU Organization}

As in the case of Parc de La Haye (Map N²00b, Point E (1)) (Vincent, 2013) (Tomezzoli, 2018), the BDU barracks, after the WWII, were not dismantled but lodged Angers peoples. This preserved the original BDU structure and allows today at more than seventy years from the end of the WWII, by analysing French air reconnaissance images of the immediate after war, to have a precise vision of the BDU organization. Figures 1-3 permit easily to recognize the castle, its dependencies and the BDU barracks and bunkers. 


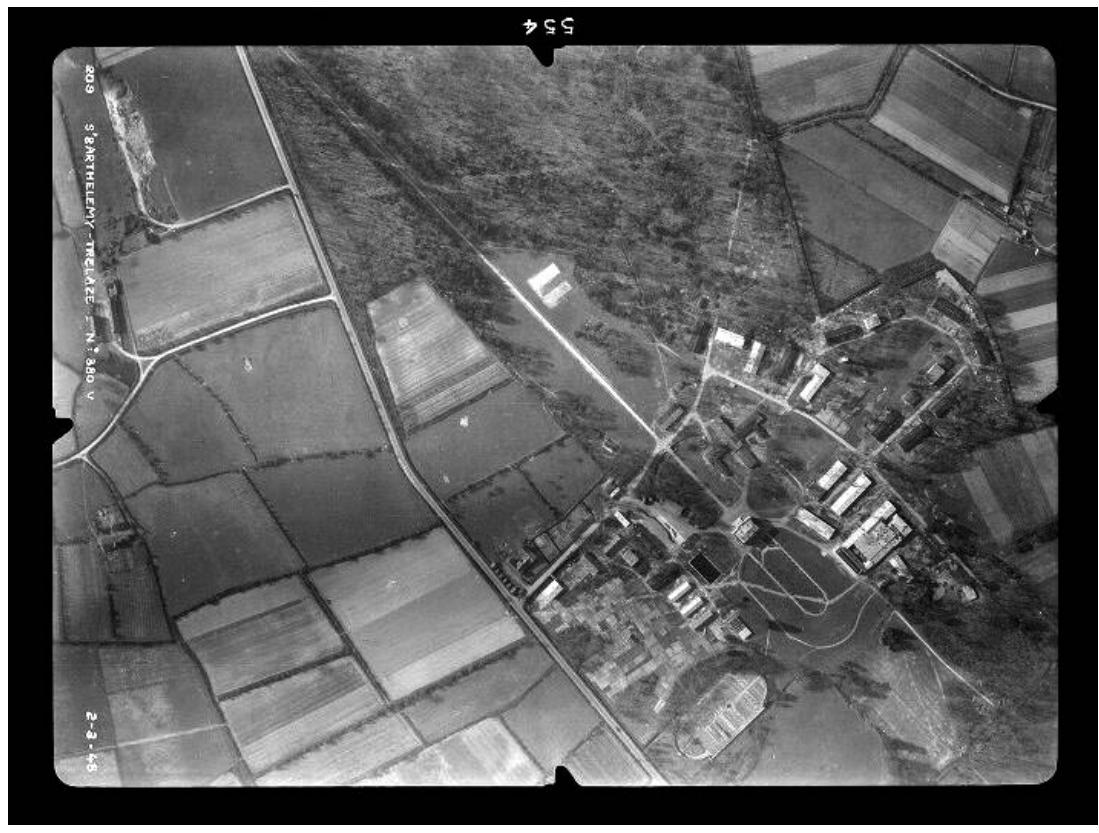

Figure 1. Domaine of Pignerolle: general view of the BDU: on the lower right, the castle and the BDU barracks and bunkers. C1522.0501_1948_CDP2928_0380, n³80, 1/4866, Argentique, 02/03/1948.

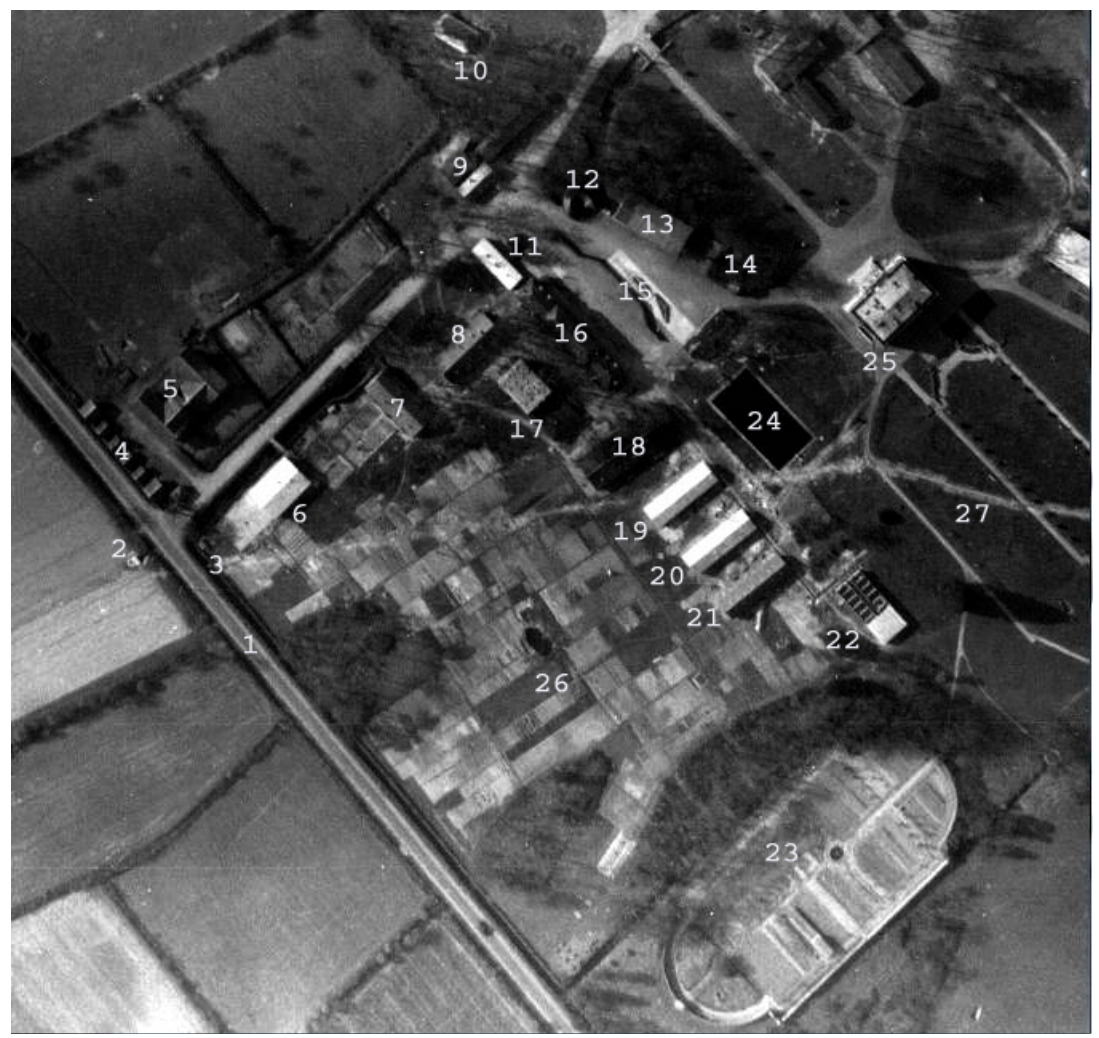

Figure 2. BDU organization-South part: (1) route de Beaufort; (2) external guard post; (3) internal guard post; (4) six small barracks; (5) two corps barrack; (6) - (8) barrack; (9) three corps barrack; (10) bunker; (11) barrack; (12) pigeon house; (13) - (15) barrack; 16 castle dependence; (17) bunker; (18) - (22) barrack; (23) vegetable garden; (24) pool; (25) castle; (26) cultivated area; (27) internal path. 


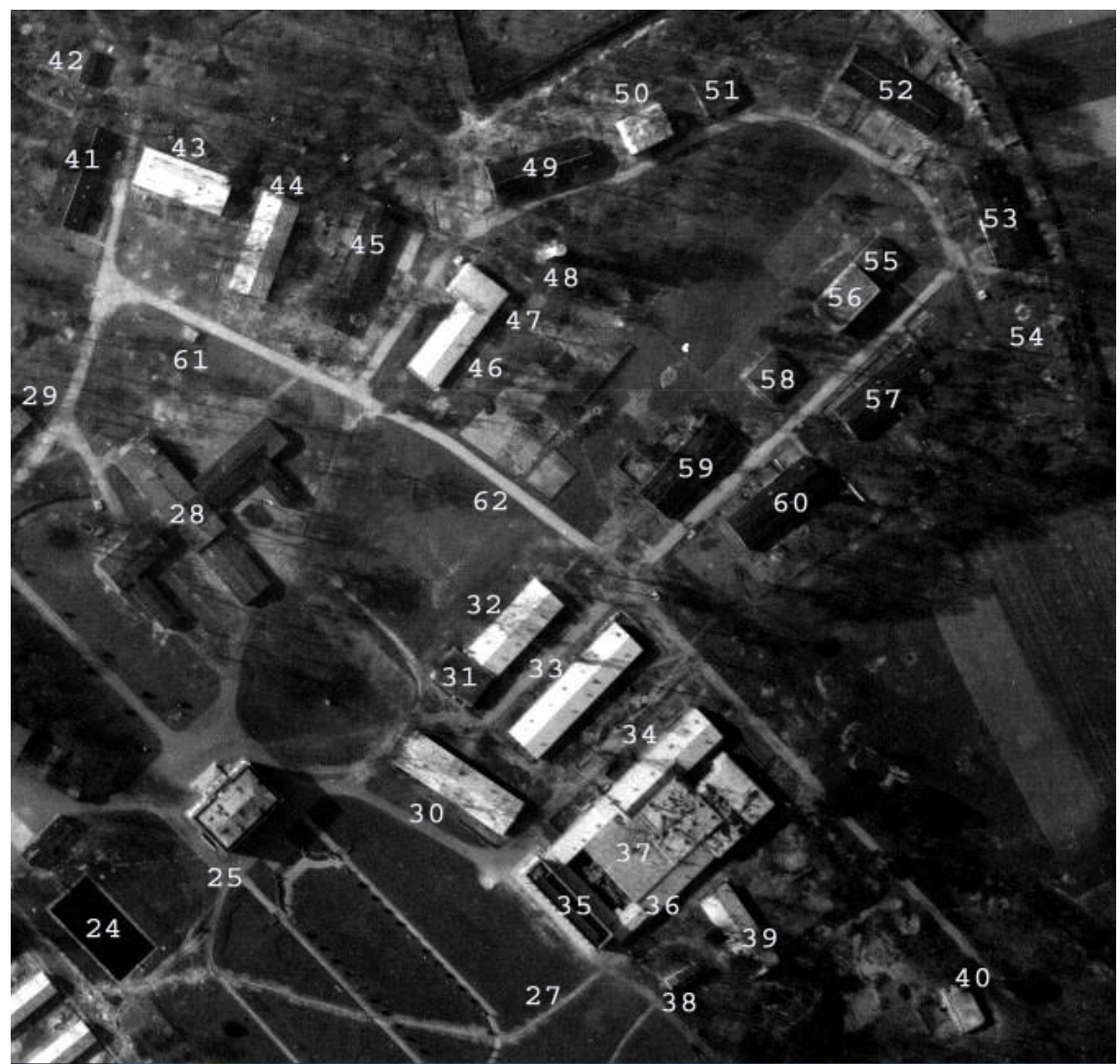

Figure 3. BDU organization-North part: (24) pool; (25) castle; (27) internal path; (28) administrative building; (29) - (30) barrack; (31) bunker; (32) (33) barrack; (34) barrack leaning to the Admiral bunker, (35) orangery, (36) barrack leaning to the Admiral bunker, (37) Admiral bunker, (38) (39) barrack; (40) bunker, (41) - (46) barrack; (47) bunker; (48) water tower; (49) barrack; (50) bunker; (51) - (53) barrack; (54) possible Flak position; (55) barrack leaning to the bunker (56); (56) bunker; (57) - (61) barrack, (62) internal path.

The visits of the BDU site took place on $22^{\text {nd }}$ August 2011 and $16^{\text {th }}$ September 2016. They showed that the pavilion tours and grids at the Domaine entrance, the entrance gate, the pigeon house (12), the pool (24), the castle (23) $\left(47^{\circ} 28^{\prime} 11.48^{\prime \prime} \mathrm{N}\right.$, $0^{\circ} 28^{\prime} 25.26^{\prime \prime} \mathrm{W}, 42.29 \mathrm{~m}$ ), the castle dependence (16), the vegetable garden (23) and the orangery $\left(47^{\circ} 28^{\prime} 14.48^{\prime \prime} \mathrm{N}, 0^{\circ} 28^{\prime} 21.98 \mathrm{~W}, 42.52 \mathrm{~m}\right.$ ) (Figure 4) were perfectly restored with no damage due to the population looting. A museum dedicated to the communication was open in the castle, but was closed at the time of the second visit (Tomezzoli et al., 2013).

The barracks (4) - (6), (9) - (11), (13) - (16), (18) - (22), (28) - (30), (32) - (34), (36), (38) - (39), (41) - (46), (49), (51) - (53), (55) (57) - (61) disappeared and only different grass growths here and there on the meadows betrayed their past presence. Rests of the concrete base of the barrack (34) were visible near the Admiral bunker (37). The water tower (48) disappeared. The concrete barracks (7) (8) were perfectly restored with no damage due of the population looting and hosted offices of the Domaine garden service.

The BDU surviving components (Figures 5-7) included the bunker (10) buried 


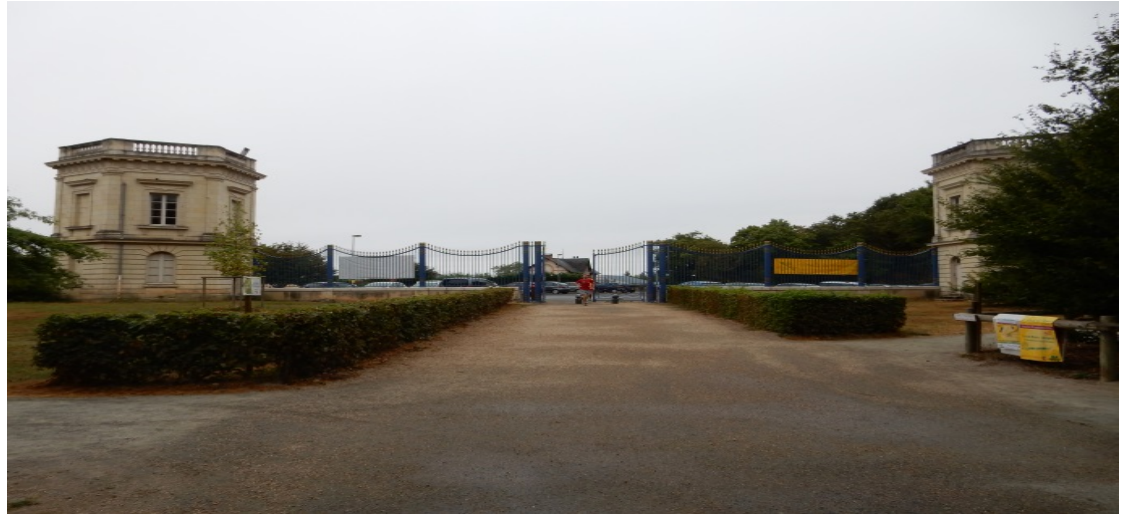

(a)

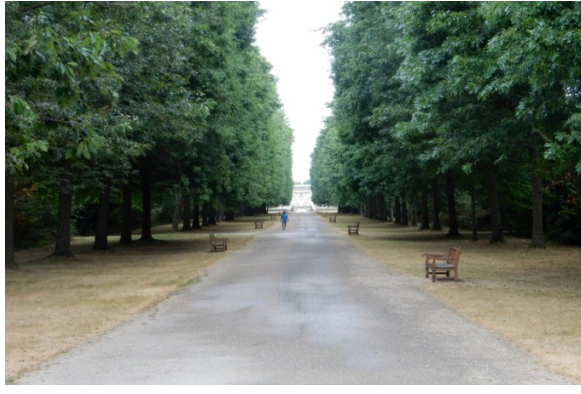

(b)

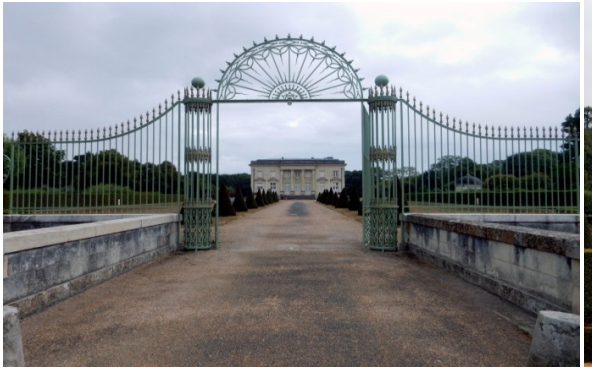

(d)

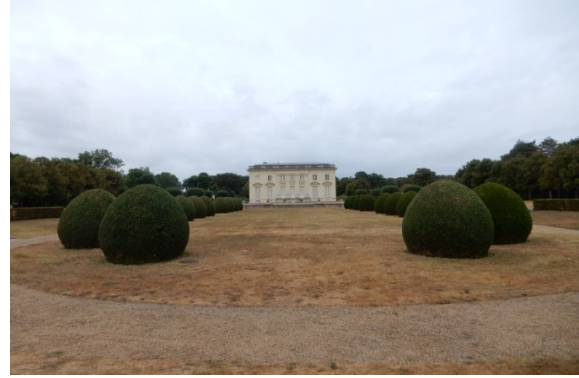

(f)

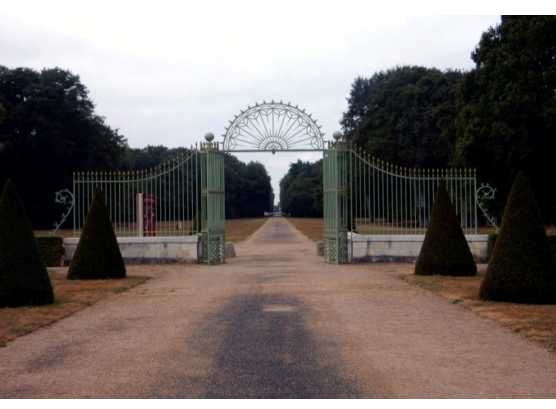

(c)

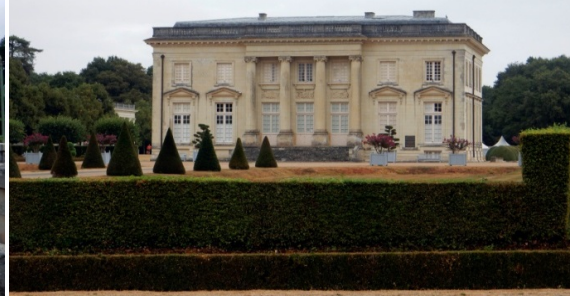

(e)

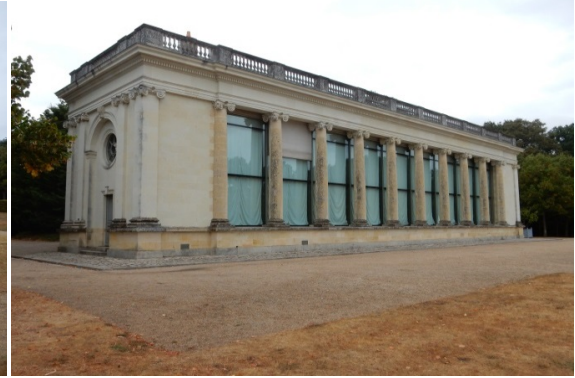

(g)

Figure 4. BDU site surviving components-(a) pavilion tours and grids at the Domaine entrance; (b) access lane; (c) entrance gate; (d) castle gate; (e) castle (25) front facade; (f) castle (25) rear facade, (g) orangery (35).

in the terrain; so that its type and internal and external preservation states have not been ascertained. The bunker (17) was accessible and used by the Domaine garden service. Its entrance side was covered by vegetation and a recent wood 


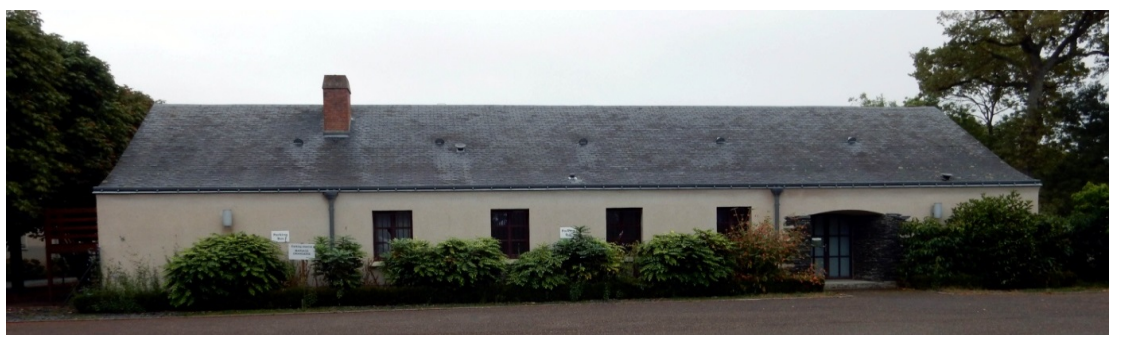

(a)

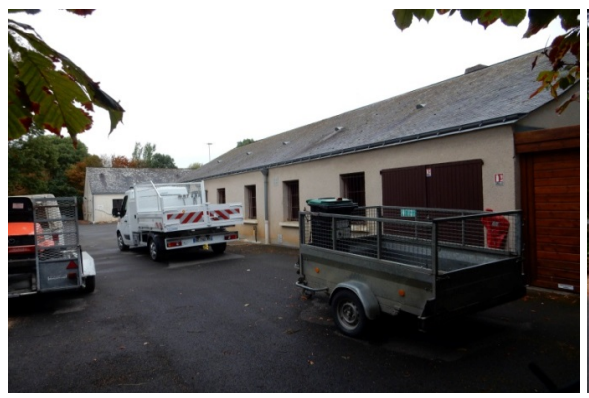

(b)

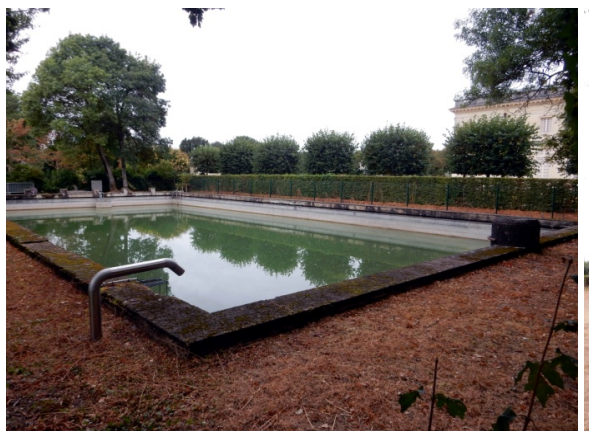

(d)

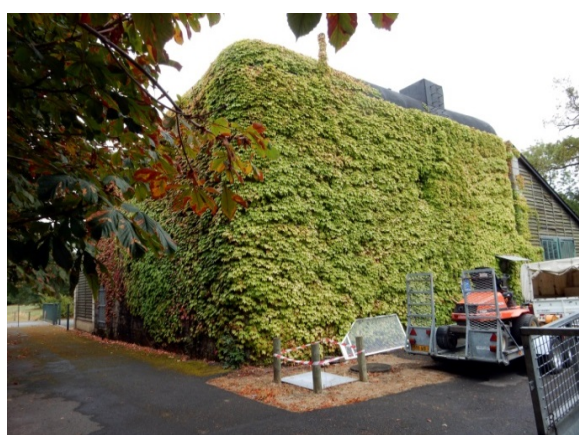

(f)

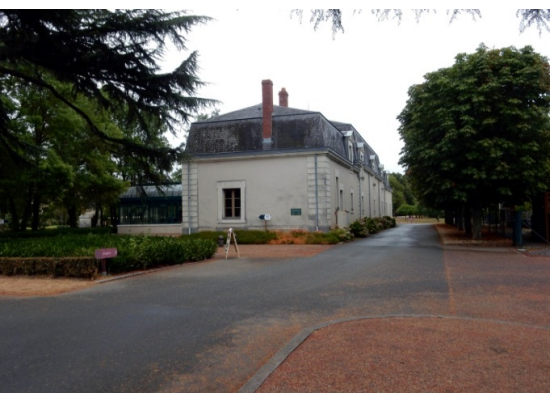

(c)

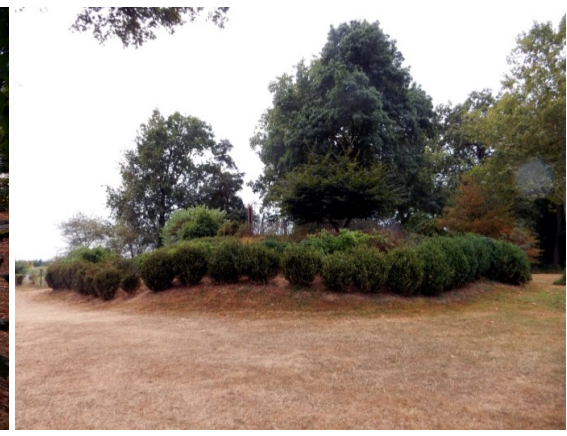

(e)

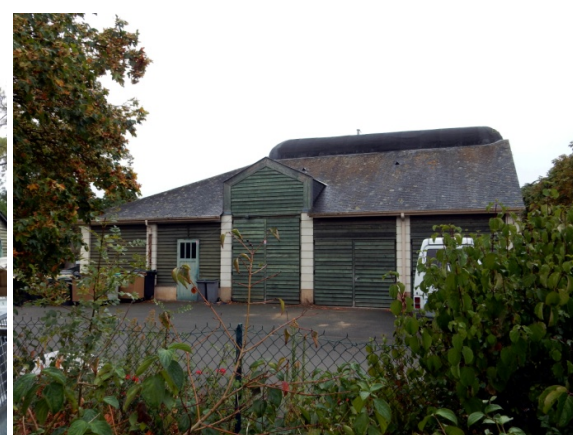

(g)

Figure 5. BDU site surviving components-(a) barrack (8) front side; (b) barrack (8) rear side-on the far left barrack (7); (c) castle dependence (16); (d) pool (24); (e) mound covering bunker (10); (f) bunker (17) entrance side; (g) barrack hanging on bunker (17).

barrack, used as garage and store of garden materials, was leaning on the opposite bunker side. The interior was in good preservation state with original armoured doors still in place. Bunkers (31), (47), (56) closed during the first were accessible during the second visit. Their interiors were in good preservation state with armoured doors still in place. All the original furniture and components of 


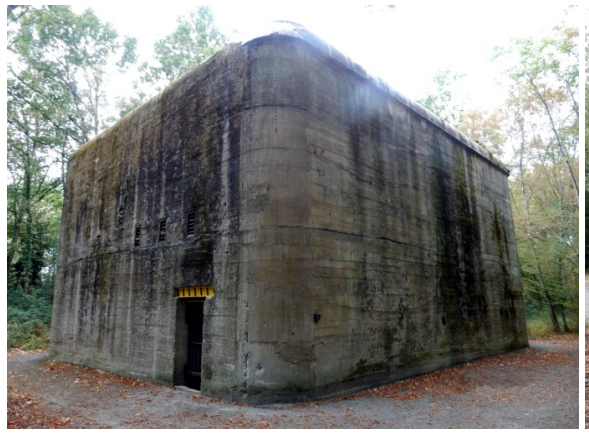

(a)

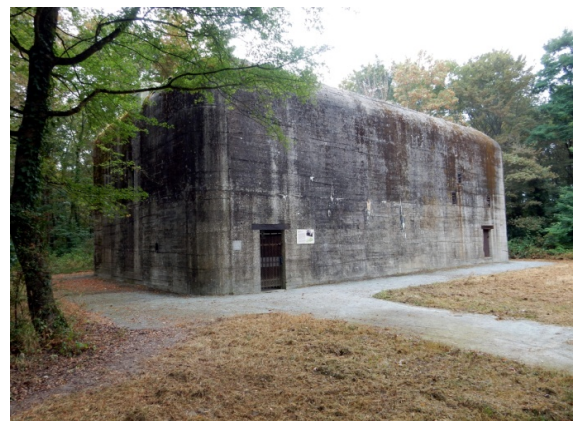

(c)

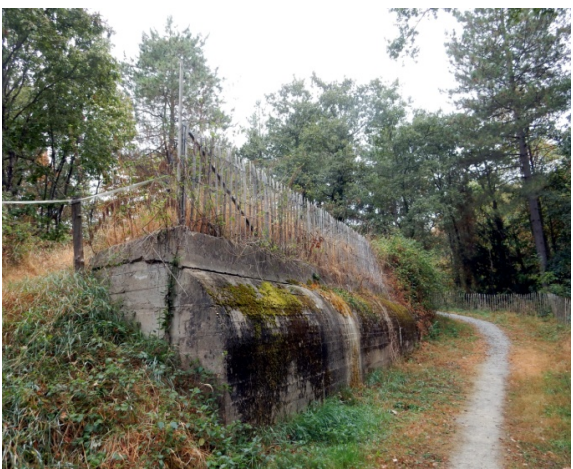

(e)

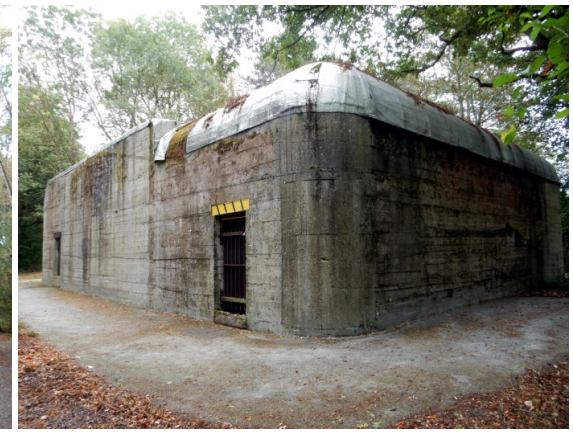

(b)

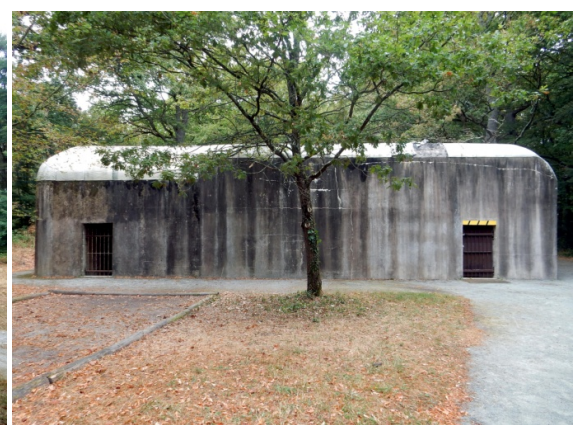

(d)

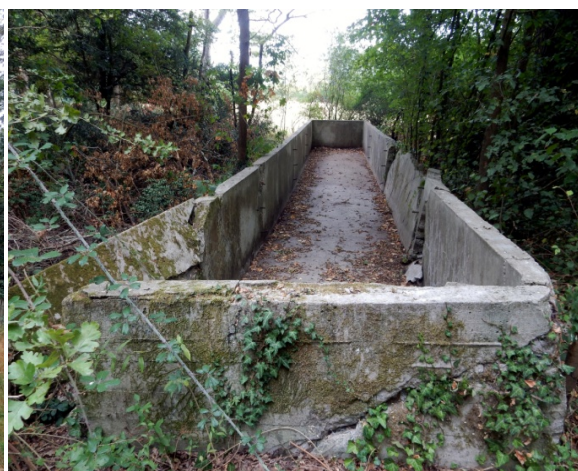

(f)

Figure 6. BDU site surviving components-(a) bunker (47); (b) bunker (50); (c) bunker (56); (d) bunker (31); (e) bunker (40); (f) concrete cistern.

its heating and aeration system disappeared. Only aeration conduit portions were in place on the walls. Their external concrete structures were in good preservation state. The coverage of bunker (31) was further covered by a recent metal sheet. Bunker (50) was accessible during the first visit. Its interior was in good preservation state with armoured doors still in place. All the original furniture disappeared and only aeration conduit portions were in place on the walls. Its external concrete structure was in good preservation state and the coverage was further covered by a recent metal sheet.

Admiral bunker (37) (about $1265 \mathrm{~m}^{2}$ ) had the external structure in good preservation state. It was not accessible at the time of the first visit; therefore its interior preservation state has not been ascertained (Tomezzoli et al., 2013). However, its interior (Figure 11(a)) rooms (27) were used for radio reception, code 


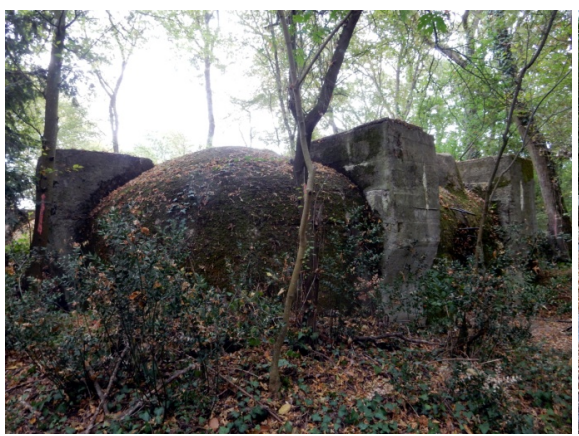

(a)

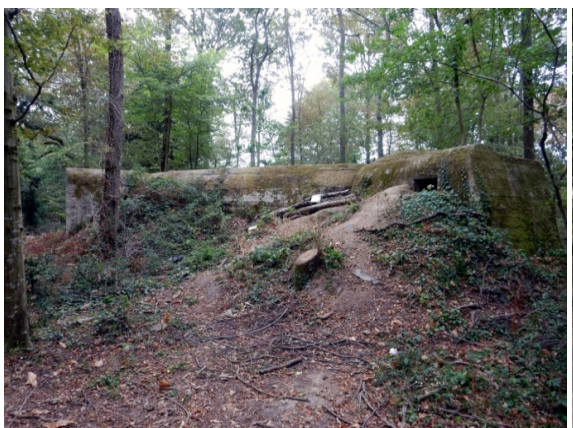

(c)

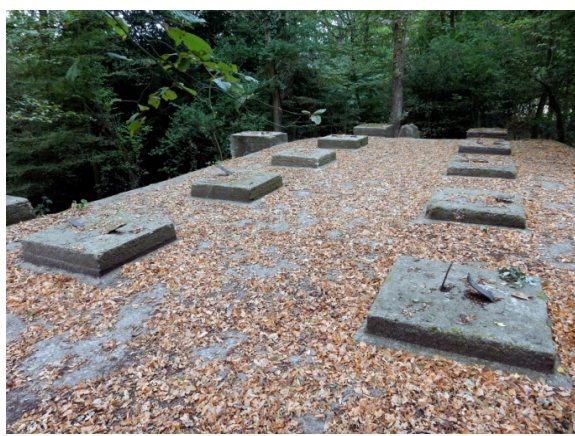

(b)

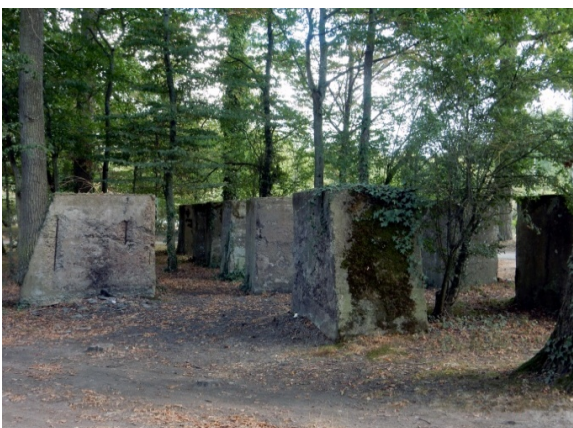

(d)

Figure 7. BDU site surviving components-(a) Sonderkonstruktion-side view; (b) Sonderkonstruktion-coverage with square supports bases; (c) R 611 or R 621-entrance side; (d) concrete aligned supports.

ciphering/deciphering and order transmissions through the antennas on the bunker coverage, which had top in shape of bicycle wheel; rooms (57) were used for statics about the sunken tonnage, calculations about the moonrise on all the seas and oceans, stored maritime maps, documents and files containing information about each U-Boot (Coiffard, 2006).

Bunker (40) was partially buried in the terrain, which obstructed its entrance. Therefore, its type and interior preservation state has not been ascertained. The emerging portion of its external structure was in good preservation state. A concrete cistern and two other bunkers $\left(47^{\circ} 28^{\prime} 9.34^{\prime \prime} \mathrm{N}, 0^{\circ} 28^{\prime} 8.35^{\prime \prime} \mathrm{W}, 43.6 \mathrm{~m}\right.$ ) (Figure 6 \& Figure 7), outside Figure 2, were about $150 \mathrm{~m}$ east from the vegetable garden (23). The concrete cistern $(2.5 \times 10 \mathrm{~m})$ was invaded by the vegetation at the time of the first visit but emptied and cleaned up at the time of the second visit. The bottom was in good preservation state, but the side walls were marked by large and deep cracks and some wall portions were displaced. One of the bunkers was of a special type (Sonderkonstruktion) partially buried in the terrain, which obstructed its entrance. Therefore, its interior organization and preservation state has not been ascertained.

Its emerging structure was in good preservation state with an obstructed emergency exit and eighteen square, support bases on its coverage. The other was an R611 or R621 partially buried in the terrain, which obstructed its fire room openings. Therefore, its interior preservation state has not been ascer- 
tained. Its emerging structure was in good preservation state, with the circular aperture of the external observation post (tobruck) obstructed by a concrete layer.

Thirteen concrete aligned supports $\left(47^{\circ} 28^{\prime} 28.02^{\prime \prime} \mathrm{N}, 0^{\circ} 28^{\prime} 23.21 \mathrm{~W}, 31.85 \mathrm{~m}\right)$ (Figure 7(d)), outside Figure 3, were about $380 \mathrm{~m}$ from the Admiral bunker beyond the state road 347 but still on the Domaine. Their external structure was in good preservation state with metallic joints still in place (Tomezzoli et al., 2013).

\section{The Admiral Bunker}

The second visit confirmed the good preservation state of the Admiral bunker external structure. On a wall the traces of the leaning barrack (36) were visible. No camouflage was painted on its coverage, and thirteen original antenna bases on the coverage disappeared.

The bunker interior (Figures 8-10) was accessible through the stair (A) which introduced to the underground tunnel towards the castle and the bunker entrance.

Both were in good preservation state with traces of construction formworks on the walls typical of the German masonry. The bunker anti-atomic transformation works were immediately evident.

A recent shower system was in place at the entrance, complete with its white rectangular base, hot and cold water mixing taps, but no splash guard. Recent toilets were in good preservation state. All the original armored doors were in

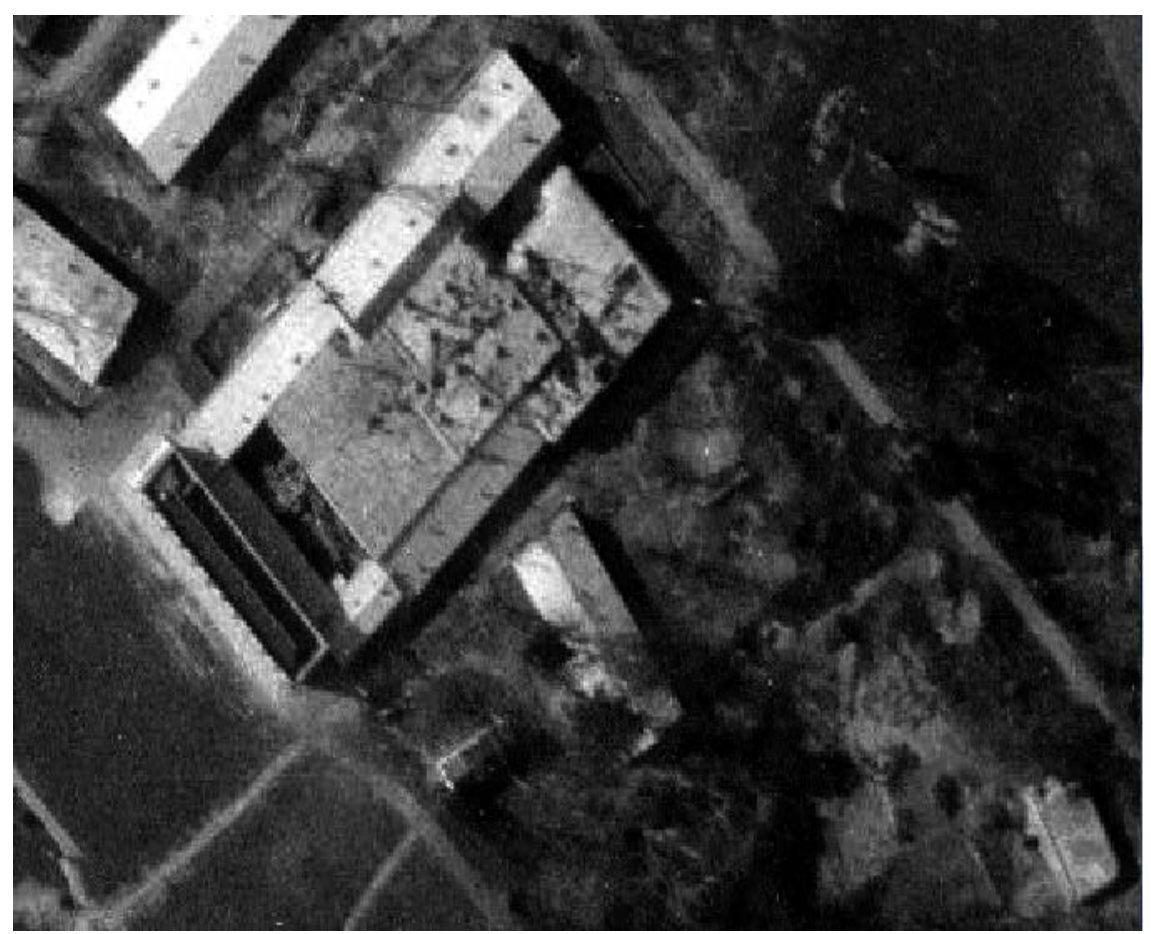

Figure 8. Admiral bunker (37)—on the left barracks (30), (33), the hanging barracks (34), (36), on the right barracks (38) (39) and bunker (40). 


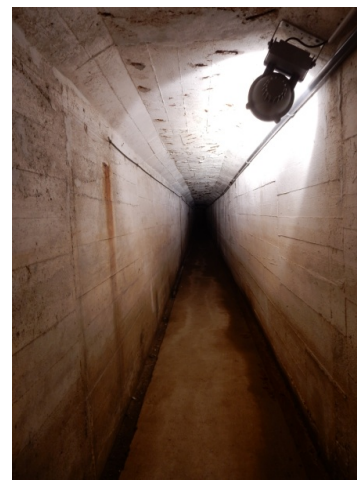

(a)

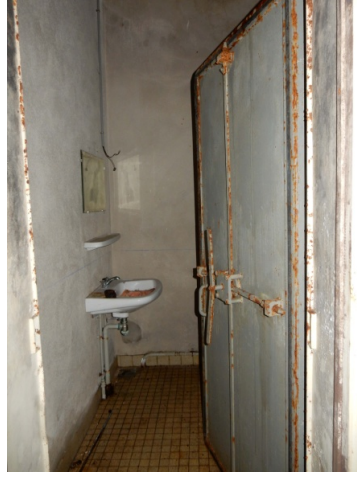

(d)

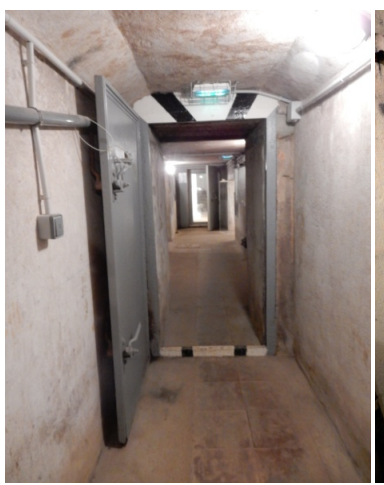

(b)

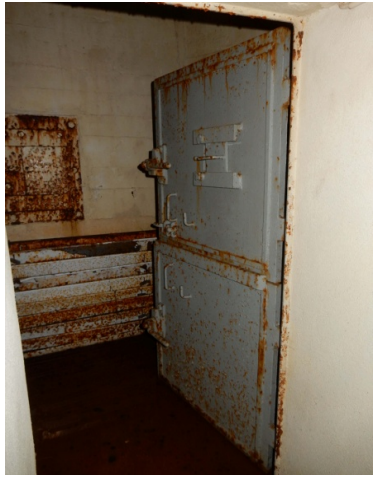

(e)

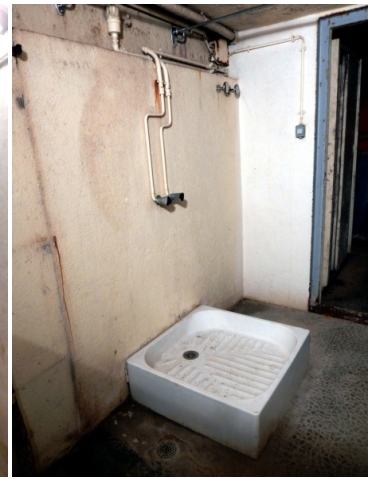

(c)

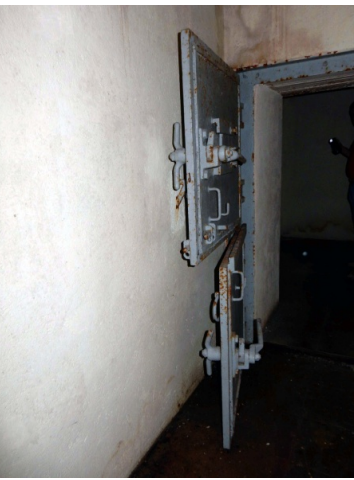

(f)

Figure 9. Admiral bunker (37) - (a) tunnel towards the castle; (b) bunker entrance, original light armored door 19P7; (c) shower system; (d) toilet in good preservation state; (e) original heavy armored door 434PO1 of a close combat defence room (2), on the wall defence original plate 483P2; (f) original armored port 434PO1.

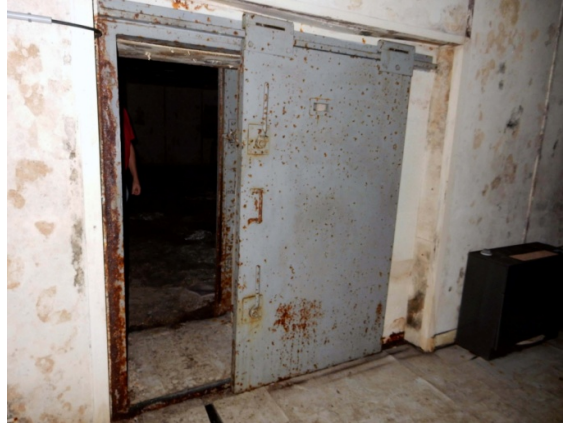

(a)

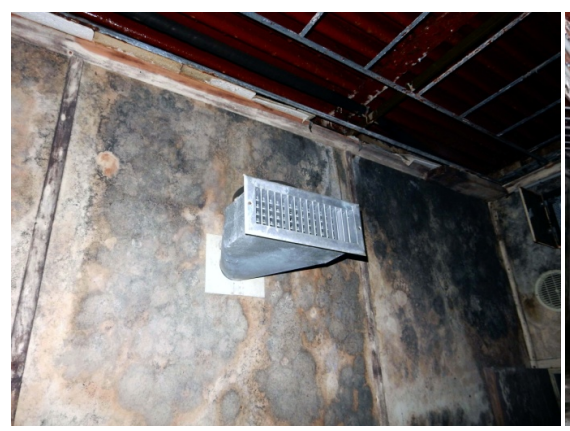

(c)

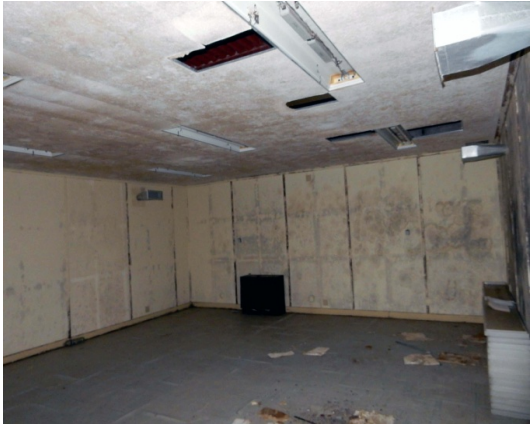

(b)

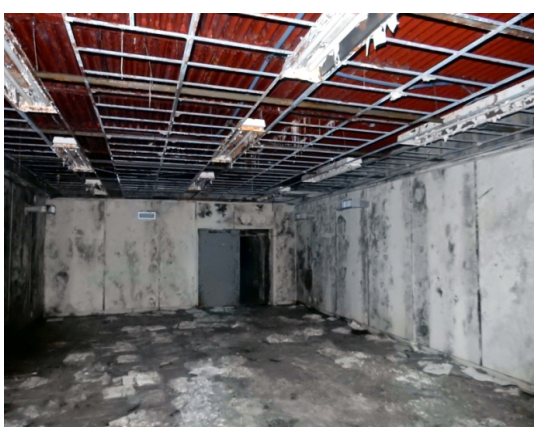

(d) 


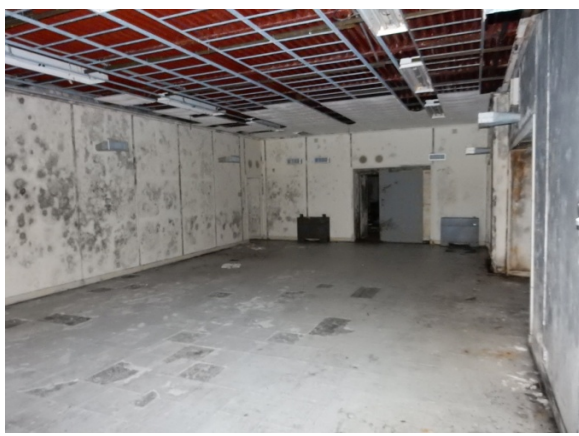

(e)

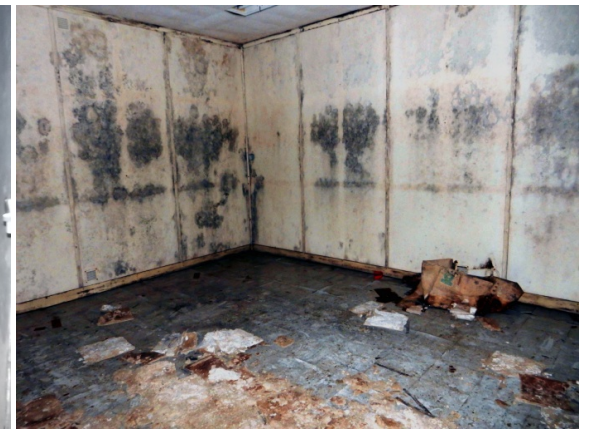

(f)

Figure 10. Admiral bunker (37) - (a) armored sliding door, on the right electrical, heating element; (b) internal room, suspended ceiling with white coverage panels in place; (c) modern galvanized aerator; (d) internal room, metallic suspension frame in place and white panels fallen on the floor; (e) internal room with metallic suspension frame and no white coverage panels; (f) internal room, white painted walls with marked traces of moisture.

place, sometime gray re-painted, sometime rusted but preserving their original blue painting.

The rooms (27), (32), (57), (85) were in a degraded state. The walls preserved the original white painting with marked stains of moisture. Original vertical wooden supports for a possible insulation system were in place. Modern galvanized sheet aerators on the walls replaced the original aerators. Original white tiles were in place on the floors. Somewhere, water puddles invaded the room floors. Modern suspended ceilings formed by white painted metallic suspension frames supported white coverage panels and casings of the lighting system each containing two neon tubes. The lighting system installation appeared completed. The panels fallen on the floor in one room let visible the suspension frame and the original, rusted bunker metal ceiling. One room was provided with suspension frame and casings but the panel installation was not terminated.

A room hosted a complete kitchen comprising a four leg electrical vegetables washing device Bonnet, a two-bowl sink furniture, an electrical cooking furniture having two circular plates, a hoven, a hot water reservoir, and a dishes furniture. Canteen furniture was not remarked in the room and in the nearby rooms.

A corridor introduced to the emergency electrical generator room (79) (Figure 11 \& Figure 12) closed on one side toward the exterior by an original double armored door 722P3. Two identical, well preserved, black painted electrical pumps each complete with control cabinet and cylindrical white painted distributor connected to white insulated conduits were in place on one room side. The conduits ascended to the ceiling and many red painted taps of the kind used on water conduits were on them. Galvanized, rectangular conduits of the aeration system ascended too to the ceiling. Four well preserved, grey painted pumps were connected with a portion of the conduits by cylindrical and galvanized conduits. Each pump was powered by a blue painted electrical motor but 


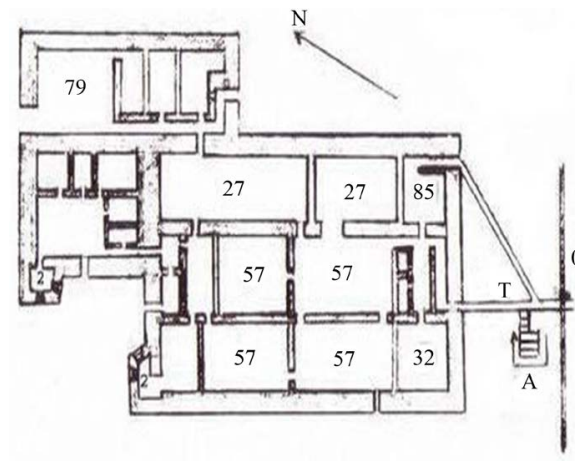

(a)

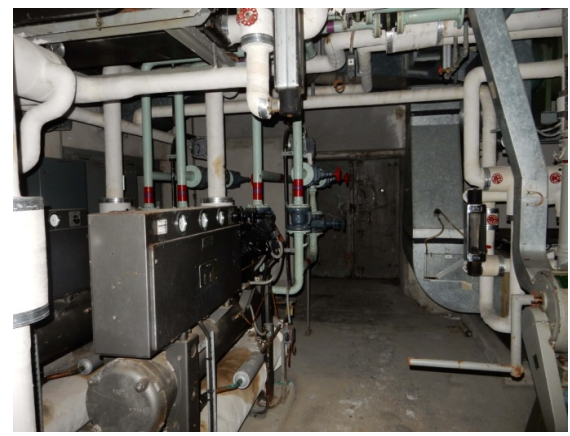

(c)

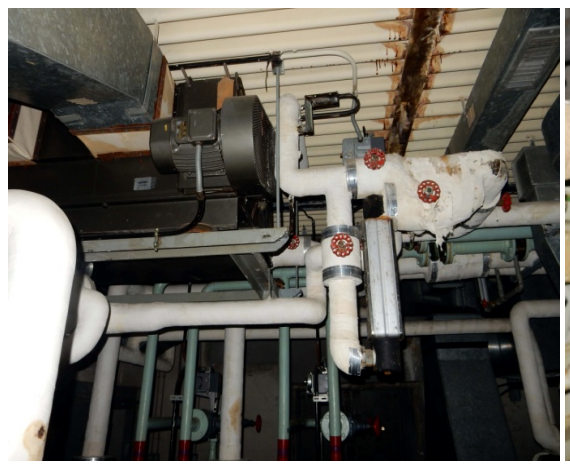

(e)

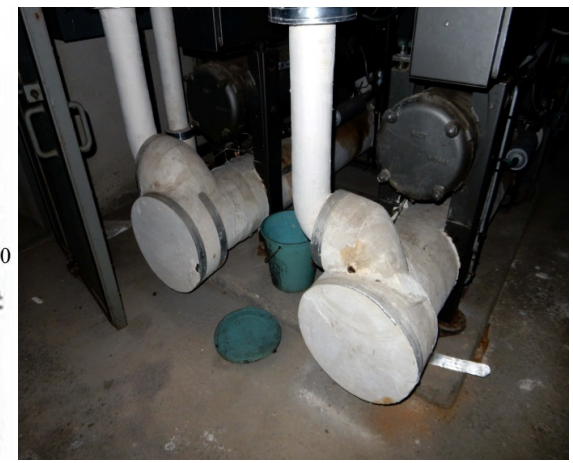

(b)

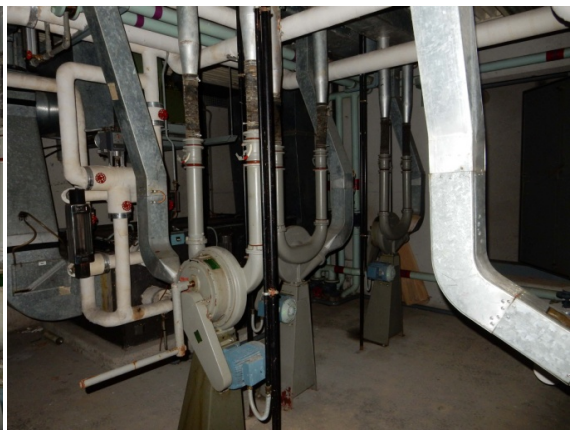

(d)

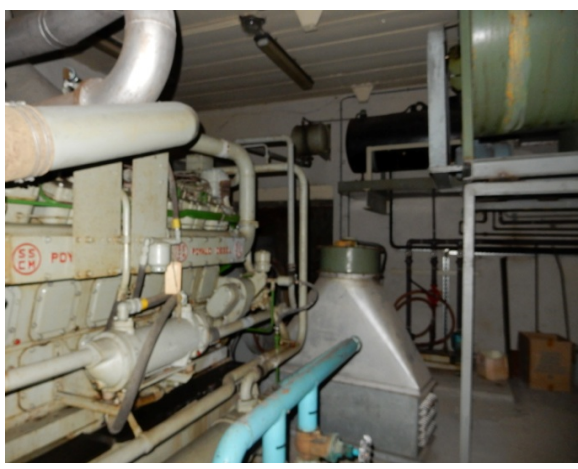

(f)

Figure 11. Admiral bunker (37): (a) plan: 2 close combat defence room, 27 computing room, 32 commander (Admiral room), 57 operation room, 79 emergency current, 85 foreman, A access stair, O orangery, T tunnel to the castle (Coiffard, 2006)—numbering according to Rudi, 1998; (b) black painted, electrical pumps with white distributors; (c) black pump on the left, armored door $722 \mathrm{P} 3$ in middle, galvanized conduit on the right; (d) grey painted pumps; (e) white insulated conduits with red painted taps; (f) diesel motor.

also provided with a crank for manual operation. The emergency electrical generator was in good preservation state (Figure 11(a)). It comprised a diesel motor connected to an alternator. The diesel motor hosted an oval label having the red letters SSCM inside and the red letters PDY outside. It received diesel fuel through a blue conduit, external air through a blue plastic conduit about $40 \mathrm{~cm}$ in diam. and evacuated exhausted gas through an insulated white conduit. The white painted alternator Leroy TA 450 leaked oil from its axis, and a stain formed on 


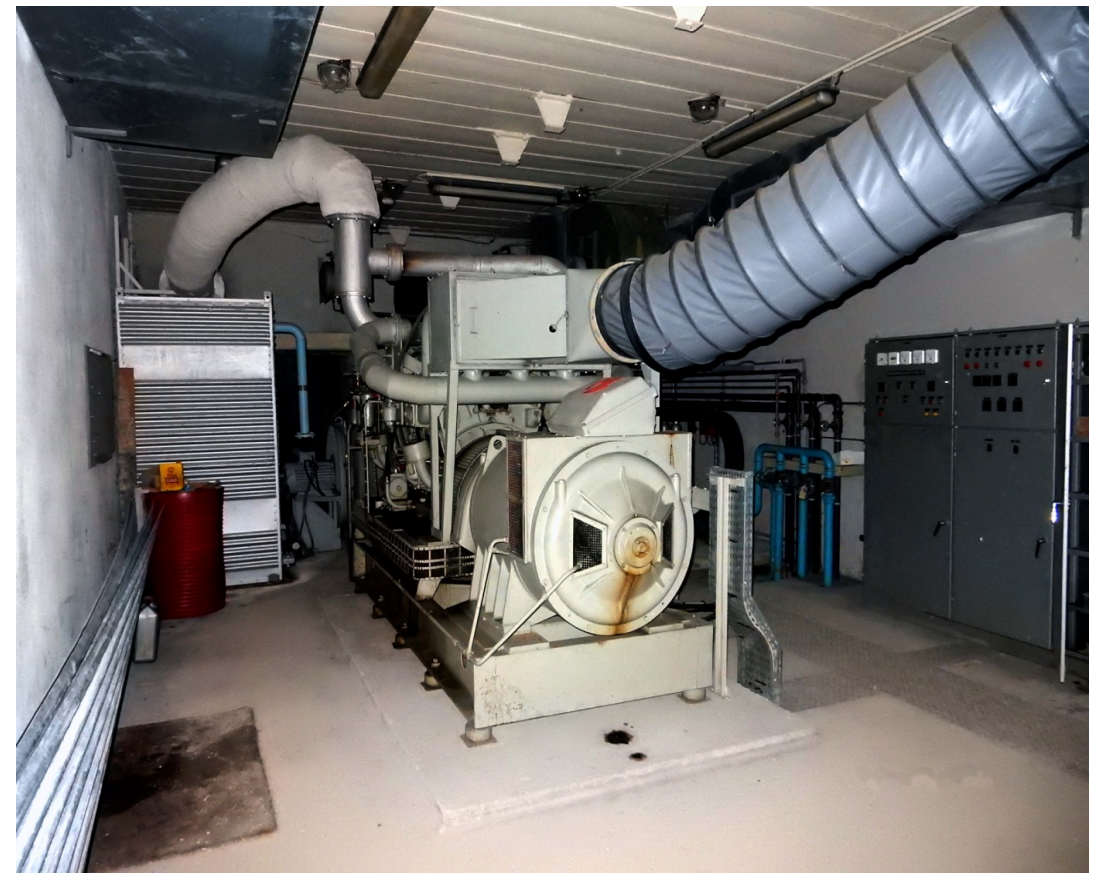

(a)

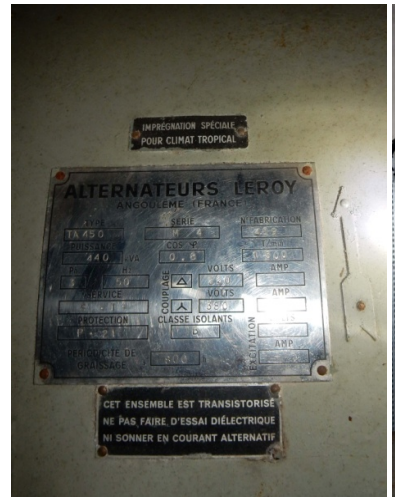

(b)

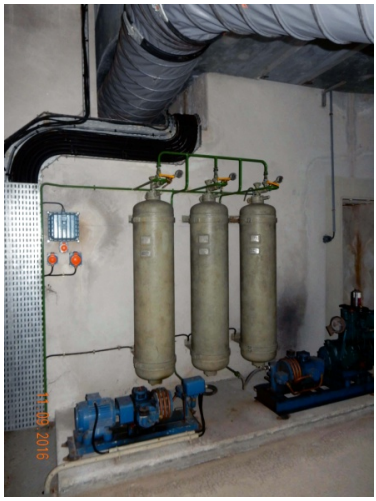

(c)

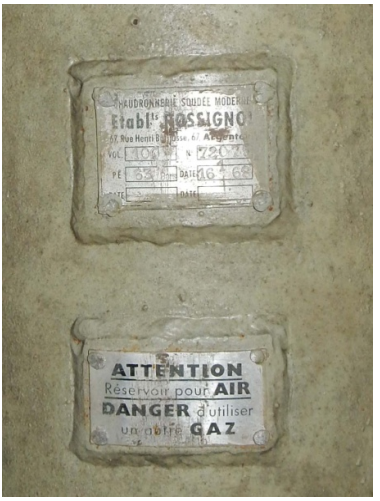

(d)

Figure 12. Admiral bunker (37): (a) alternator Leroy TA 450, on the right grey painted control cabinets, on the ceiling, joints for the generator lifting; (b) alternator data plates; (c) cylindrical bottles and two air compressors on the floor; (d) two metallic labels on one bottle.

the white painted floor. On the room ceiling, white metal joints for the generator lifting were in place. The alternator grey and blue painted control cabinets were in good preservation state. A white arrow near two metallic black data plates and a silver data plate on the alternator indicated the rotation direction. The data plates (Figure 11(b)) informed:

$$
\text { metallic black plates: }
$$

IMPREGNATION SPÉCIALE

POUR CLIMAT TROPICAL metallic plate:

ALTRENATEUR LEROY

ANGOULEME (FRANCE) 


\section{Continued}

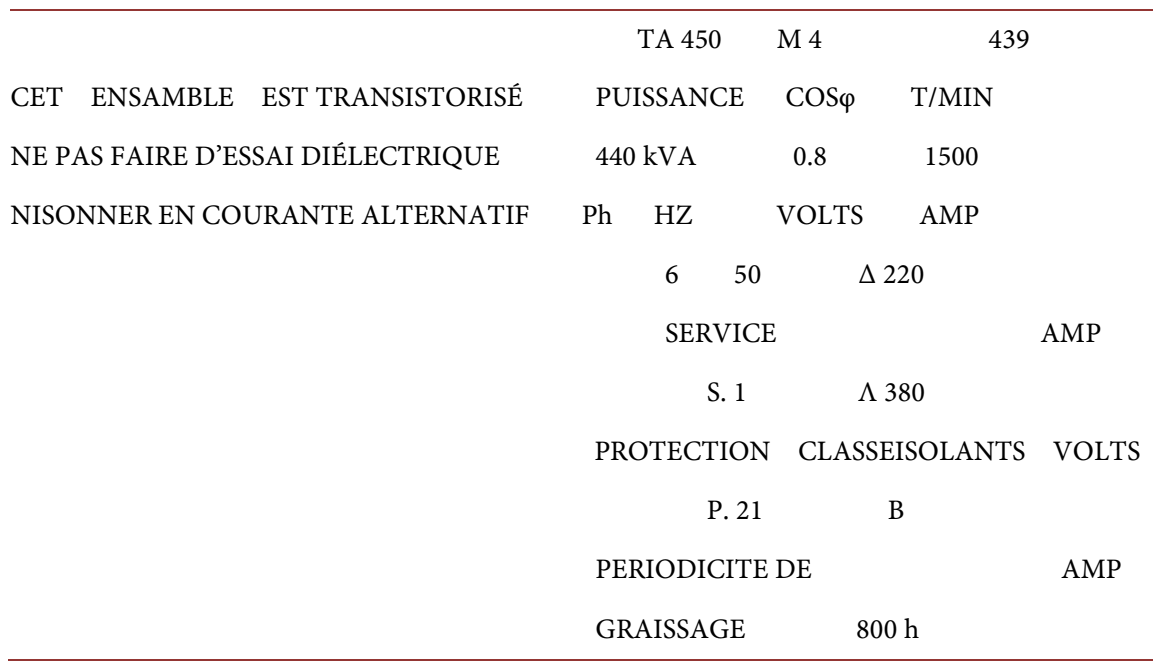

The alternator technical sheet adds, among other, the information:

\begin{tabular}{lll}
\hline Type: TA 450 M $4(420)$ & Série: ARES No: $439 \ldots$ & No de bon: 26050 \\
RECETTE EFFECTUÉE & Expedié: 22 JANV 1968 & \\
\hline
\end{tabular}

Three well preserved cylindrical, metal bottles of pressurized air were suspended to a room wall. Green tubes departed from them to the diesel motor and to two blue painted air compressors on the room floor. Two metallic data plates on one of the bottles (Figure 11(d)) informed:

\begin{tabular}{ccc}
\hline $\begin{array}{c}\text { CHAUDRONNERIE } \\
\text { Etabl }^{\text {ts }}\end{array}$ & SOUDÈE & MODERNE \\
RO, Rue Henry Balliosse, 67 Argenteuil & ATTENTION \\
Vol. 100 & N. 72075 & $\underline{\text { Réservoir pour AIR }}$ \\
PE 63 Bars & DATE $16 \quad 168$ & DANGER d'utiliser \\
DATE & DATE & un autre GAZ \\
\hline
\end{tabular}

\section{Discussion}

The components of the BDU West were spread around the castle. The castle and concrete barracks (7) (8) lodged officers. The six small barracks (4) at the BDU entrance were probably linked with the guard corps service. Barracks (5) (6), (9) - (11), (13) (14), (18) - (22), (28) - (30), (33) - (34), (36), (38) - (39), (41) - (46), (49), (51) - (55), (57), (59) - (61) and the castle dependence (16) lodged operators of the Admiral bunker, guards and service personnel and U-Boote crews back from missions or preparing for missions. The barrack (28) was formed by six joined barracks and due to its extension and central position in the BDU probably hosted different services: administration offices, post office, library, reading room, kitchens, cantinas, cinema, and theatre. The barrack (15) has un- 
common shape and unknown purpose. The barrack (22) was provided with ten opened spaces showers. Barracks (34), (36) together with the orangery camouflaged the Admiral bunker (37). Bunker (10) was an ammunition bunker buried after the war for security reasons. Due to its clear colour, the barracks (6), (9), (11), (15), (19) (20), (22), (30) - (32), (36), (39), (43) (44), (46) had a metallic roof. Due to the dark colour, the barracks (4) (5), (7) (8), (10), (13) (14), (16), (18), (21), (28) (29), (33) (34), (38), (41) (42), (45), (49), (51) - (55), (57), (59) (61) had a tile or slate roof. A parade ground is not recognizable in Figure 2 \& Figure 3, however it was probably located in the oval space between the castle and barrack (28). Pool (24) and the pool near the R611 let the BDU seamen to swim and provided water in case of fire in the bunkers and barracks, as already seen at the German bases "The Bank" (Tomezzoli, 2016) and Kerlezerien (Tomezzoli, 2013). A blue plate of $8^{\text {th }}$ April 2000 on a side of the castle dependence informed in French that: "After the Second World War, because of the housing crisis, nearly a thousand inhabitants of Angers were lodged in the barracks left in this place by the German army".

The bunker (31) was an infirmary bunker. Bunkers (47), (50), (56) were shelters for the BDU seamen in case of attack. The purpose of bunker (40) is unknown. The R611 was a bunker for a $150 \mathrm{~mm}$ gun; the R621 was a shelter for personnel. In case of R611, this bunker protected the east side of the BDU and it is surprising that no other such bunker was built for protecting the other sides of the BDU. The square support bases on the Sonderkonstruktion coverage probably supported a Flak guns platform. The thirteen concrete aligned supports probably supported another Flak guns platform. The cistern was probably the first constructed near the R611 or R621 and the Sonderkonstruktion. It stored water necessary on the construction yard of said bunkers, and not easily available on the yard. It provided water for knead the concrete, to quench thirst of working animals and against possible fires of the wood stocks for formworks.

All the U-Boote missions were coordinated at the Admiral bunker. All its original German furniture and sensitive devices disappeared looted by the population or confiscated by the American or French military authorities. The original heating system, ventilation system, electrical system, illumination system and antenna bases on the bunker coverage disappeared during the transformation works in anti-atomic bunker. The recent metal covers on bunkers (31), (50) were probably placed at the time of the transformation works. The shower system in place at the bunker entrance was a decontamination device. The incorrect location of the emergency generator in the bunker Admiral plan (Coiffard 2006) has been corrected in Figure 9. The original double armored door 722P3 facilitated the introduction of materials in the room (79). The diesel motor and alternator Leroy TA 450 replaced the originally installed diesel motor and alternator damaged by the fire. The vintage images of the original diesel motor and alternator of the bunker did not permitted to ascertain whether they were of German construction or rather of French construction as those installed at the German 
submarine base of La Pallice or that of the French diesel-electric locomotive 262 AD. 1 or 262 BD. 1 of the degaussing station at the Bouvet basin of Saint-Malo port (Tomezzoli \& Pottier, 2016). The original radiators, visible in vintage images, were replaced by electrical, heating elements. The black pumps and the insulated, white tubes circulated hot water of the heating system. The grey pumps, the galvanized tubes and aerators circulated air of the ventilation system. The blue tube distributed diesel fuel to the diesel motor. The bottles and the green tubes circulated compressed air to the diesel motor. The dates 16168 on a metallic label of an air bottle and the 16 JANV 1968 on the technical sheet of the Leroy alternator permit to date the transformation works of the Admiral bunker between the 1964, year of the closure of the BDU as provisory accommodation centre and the year 1968 .

The presence of a complete kitchen, room electrical, heating elements, a complete lighting system and a complete emergency electrical generator suggest that the transformation of the Admiral bunker in anti-atomic bunker was in an advanced phase of completion, but the suspension frame with incomplete tile coverage in one room, the absence of canteen furniture and the total absence of furniture in rooms (27), (32), (57), (85) suggest that the adaptation of the bunker was not completed and consequently it never was operative.

\section{Conclusion}

The reason of the disappearance of the BDU barracks was clearly the Saint Barthelemy and Angers housing expansion after the WWII. On the other hand, the reasons of the transformation works of its Admiral bunker in anti-atomic bunker for the French president and government, despite the existence already from 1963 of an anti-atomic commandment place coded Gypse at the BA 921 base near Taverny and another one under a hill near Lyon, and the reasons of the interruption of said transformation works remain to be determined.

\section{Acknowledgements}

I wish to thank Mr. C. Marquet of the French Association "Les Oubliés de Pignerolle" who allowed me to visit the Admiral bunker, Mr. D. Kugler and Mr. J. Kreutz of the European Patent Office for the stimulating discussions concerning the emergency electrical system, Mr. De Butler of Leroy-Somer company for the technical sheet of the Leroy TA 450 alternator and Mr. Fleuridas for his information concerning the R611, R621, the Sonderkonstruktion and the concrete cistern.

\section{Conflicts of Interest}

The author declares no conflicts of interest regarding the publication of this paper.

\section{References}

Coiffard, J.-L. (2006). Domaine de Pignerolle - Temoin d'une grande Histoire. Château-Musee 
de la Communication-Angers Loire Tourisme.

Gautier, R. (1973) Récit du Colonel Gautier. Courrier de l'Ouest, 4-1-1973.

Lemesle, M. (1981). Angers sous l'occupation. Ouest France.

Rudi, R. (1998). Typologie du Mur de l'Atlantique. Beetsterwaag, NUGI 923.

Suquet, G. (2009). Mûrs-Érignéet la Deuxième Guerre Mondiale (5è ed.).

Suquet, G. (2010). D’ Anger le Danger 1942-1945. Murs Érigné.

Tomezzoli, G. (2013). Landerneau während des II. Weltkrieges, DAWA Nachrichten, Ausgabe 62, 38-59. Deutsches Atlantikwall Archiv, Köln.

Tomezzoli, G. T. (2016). The German Base "the Bank" at Mûrs-Érigné (Anjou-FR). Archaeological Discovery, 4, 37-47. https://doi.org/10.4236/ad.2016.41004

Tomezzoli, G. T. (2018). WWII German Military Structures in Angers (FR). Archaeological Discovery, 6, 300-318.

Tomezzoli, G. T., \& Pottier, L. L. (2016). Journey through the Defences of the Festung Saint-Malo(FR) - 2. Archaeological Discovery, 4, 143-169.

https://doi.org/10.4236/ad.2016.44011

Tomezzoli, G., Pottier, L., Marquet, C., \& Letertre, M. (2013) Les Installations de la Kriegsmarine au Domaine de Pignerolle, 39-45 Magazine, 60-72.

Vincent, H. (2013). Temoignage. La cité “des Baraquements” du parc de la Haye de 1944 à 1950. Wiki Anjou. 10th March 2013.

https://www.wiki-anjou.fr/index.php/Avrill\%C3\%A9_-_Parc_de_la_Haye_Val_d\%27O r_P\%C3\%A9pini\%C3\%A8res 